\title{
Crop yield and water saving potential for AquaCrop model under full and deficit irrigation managements
}

\author{
Mohmed A.M. Abdalhi, ${ }^{1,2}$ Zhonghua Jia ${ }^{1}$ \\ ${ }^{1}$ School of Hydraulic, Energy and Power Engineering, Yangzhou University, Yangzhou, China; \\ ${ }^{2}$ Department of Agricultural Engineering, Faculty of Agricultural Technology and Fish Sciences, \\ Al-Neelain University, Khartoum, Sudan
}

\begin{abstract}
The study review selected researches related to full and deficit irrigation managements simulated with AquaCrop model for various field crops (group 1) and vegetables/spices (group 2). In order to evaluate the application of full and deficit irrigation $v s$ crop yield and water use, publications from 1979 to 2018 were reviewed. With a view to find the significance variations in modelled crop yield, irrigation water use and yield reductions corresponding to water saving potential (WSP). Additionally, reporting brief summary of findings, recommendations linked to model simulation and proposed some gaps for further investigations. The findings confirm that there are significant differences in yield reductions corresponding to water saving with inference $\mathrm{R}^{2}$ was 0.372 in crop group 1 and 0.117 in group 2 during study. Simulated yield in evaluated field crops and vegetables/spices varied between 14.44 to $0.012 \mathrm{t} / \mathrm{ha}$ in full $\mathrm{ET}_{\mathrm{c}}$ and 10.72 to 0.004 $\mathrm{t} / \mathrm{ha}$ in deficit $\mathrm{ET}_{\mathrm{c}}$. The water saving potential, in the two groups of field and vegetable/spice crops revealed that, with acceptance of yield reduction equivalent 2.66 and $29.03 \%$ save irrigation water equal to 23.68 and $80 \%$ while the reduction of 41.79 and $26.86 \%$ of yield saved 28.87 and $82.1 \%$. The maximum water save values are higher than that reported for deficit irrigation in
\end{abstract}

Correspondence: Zhonghua Jia, School of Hydraulic, Energy and Power Engineering, Yangzhou University, Yangzhou 225009, China. E-mail: mohmedabdalhi@yahoo.com

Key words: Crop water productivity model; evaluation; severe water stress; simulation; water use; yield reductions.

Acknowledgements: the authors express their gratitude to the editors and reviewers, whose comments and suggestions are extremely valuable and helpful for improving this paper.

Received for publication: 31 May 2018.

Accepted for publication: 1 August 2018.

(C)Copyright M.A.M. Abdalhi and Z. Jia, 2018

Licensee PAGEPress, Italy

Italian Journal of Agronomy 2018; 13:1288

doi:10.4081/ija.2018.1288

This article is distributed under the terms of the Creative Commons Attribution Noncommercial License (by-nc 4.0) which permits any noncommercial use, distribution, and reproduction in any medium, provided the original author(s) and source are credited. previous publications. Some suggested points related to this research need further studies e.g. evaluating the big differences in crop yields and irrigation water applied resulted with AquaCrop under full and deficit irrigation management and justification of high WSP corresponding less crop yield reduction.

\section{Introduction}

The real challenge of the agricultural sector is to be able of feeding world population that is rapidly growing over time and try to decrease the water usage in the sector. The world's population numbered nearly 7.6 billion as of mid-2017 and this number is projected to increase by slightly more than one billion people over the next years, reaching 8.6 billion in 2030, and to increase further to 9.8 billion in 2050 (UN-Population Division, 2017). Consequently, the food demand will rise by $60 \%$ in the same period (Alexandratos and Bruinsma, 2012). Agriculture accounts for roughly $70 \%$ of total freshwater withdrawals globally and for over $90 \%$ in the majority of least developed countries (FAO, 2011). Without improved efficiency measures, agricultural water consumption is expected to increase by about $20 \%$ globally by 2050 (WWAP, 2012) or predicts the world could face a $40 \%$ global water deficit by 2030 under a business-as-usual scenario (2030 WRG, 2009).

The functionality of irrigation is not only to provide sufficient water for crops in order to achieve better outcome in production, as implied in conventional irrigation definition. Irrigation must be also contributing in improve the features such as water use efficiency, crop productivity per any drop of water applied and water saving potential. These goals will not be reached if we have not considered the irrigation schedule and calculated the precise amounts of different crop water requirements as full irrigation magnitudes in order to control the amounts of water that can be withdrawal from rivers, lakes and aquifers for irrigation purposes. Irrigation scheduling is a planning and decision-making tool used for determining the amount and timing of irrigation application for maximising efficient water use and crop yield (Joel et al., 2007). Full irrigation corresponds to the amount of water enabling the actual evapotranspiration of a crop to be equal to its potential evapotranspiration or the total water needed for evapotranspiration and cell construction, from planting to harvest for a given crop in a specific climate regime usually, addressed as crop water requirement (Frenken and Gillet, 2012). While, deficit irrigation (DI) is an optimisation strategy in which irrigation is only applied during drought-sensitive growth stages of a crop (Geerts and Raes, 2009).

Nowadays, in spite of the huge numbers of research results availability and extension services for the farmers and farm own- 
ers around the world, still there are some proposed questions which are needed to be answered such as: how the farm owners can increase production and optimise their water used, why the optimal yields are not being obtained despite the available water and required nutrient applications, what exact crop and/or water factors that are responsible for increasing or decreasing the yields in global case or regionally and how can make a pre-simulation to the crop growth and production behaviours as in real crop field for imaging the possibility of benefits and profits instead of wasting time, efforts and costs as well as contributing in save agricultural water. As objective for this study, we reviewed and analyses most of the scientific literature, which had investigated full and deficit irrigation managements in relation with crop yield and water use for different crops and regions, that were simulated with AquaCrop model. The evaluated crops are sorted into two different crop groups as following: field crops (group 1) and vegetables/spices (group 2). After comprehensive evaluation for reviewed cases and inferences, we concluded valuable observations and findings, which will be explained later in details.

\section{AquaCrop model}

\section{Model concept and comparison to other crop models}

AquaCrop (Figures 1 and 2) is a crop water productivity model developed by Food and Agriculture Organisation (FAO) (Hsiao et al., 2009; Raes et al., 2009a; Steduto et al., 2009) to predict crop productivity, water requirement, and water use efficiency under water limiting conditions (Raes et al., 2009b). The model evolved from the concepts of crop yield response to water, developed by Doorenbos and Kassam (1979). It seeks the balance among simplicity, accuracy and robustness to facilitate wide application, this multi-crop and water model requires only a relatively small number of explicit parameter values and mostly intuitive input variables, which are obtainable by straightforward methods (Raes et al., 2009b; Steduto et al., 2009; Vanuytrecht et al., 2014). AquaCrop version 5.0 interface and the main components of the soil-plant-atmosphere continuum and others useful driving parameters (Figures 1 and 2). Continuous lines indicate direct links
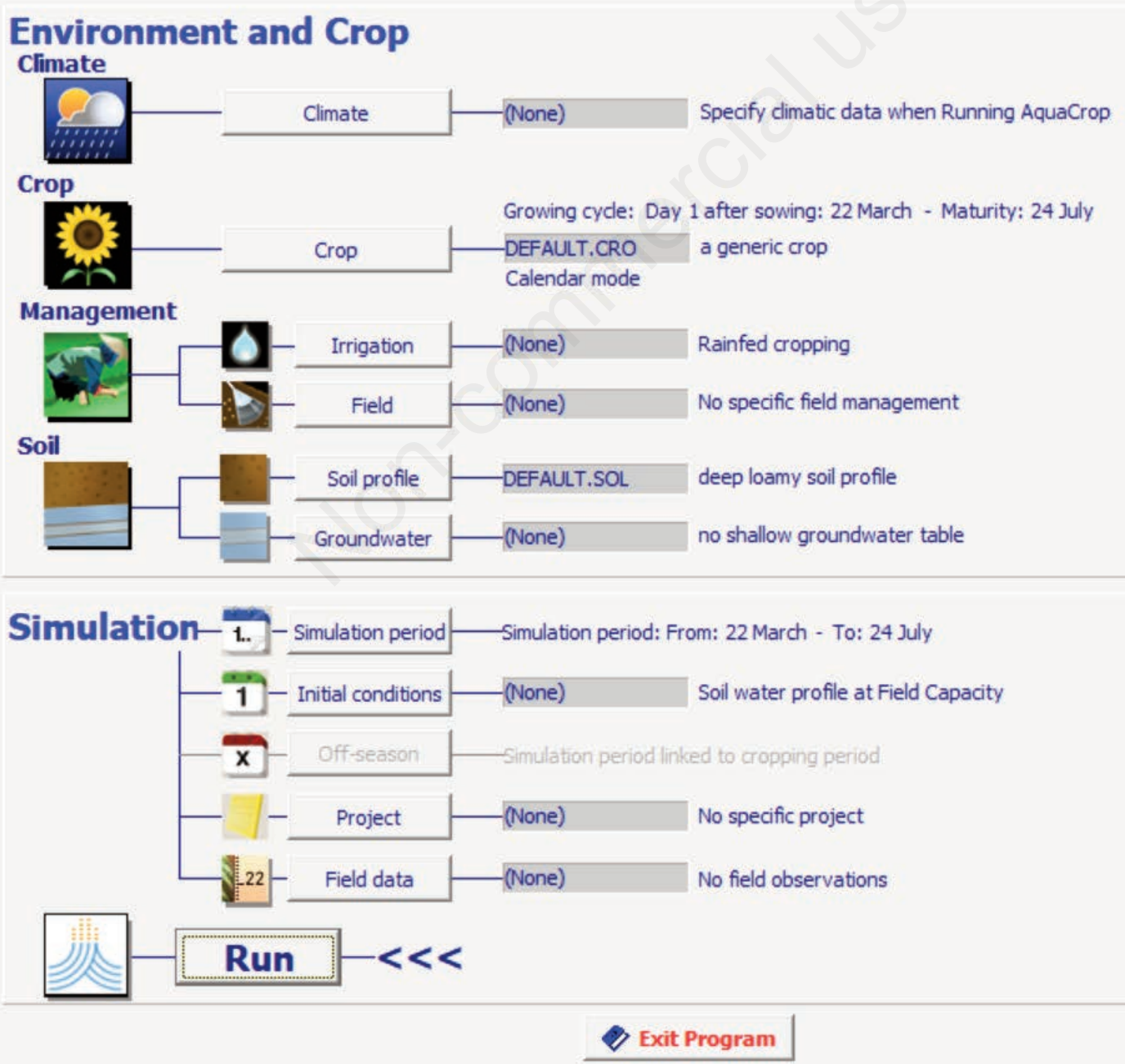

Figure 1. Main menu of AquaCrop model version 5.0, October, 2015. 
between variables and processes, while dashed lines indicate feedbacks (Steduto et al., 2007, 2009).

Use of models can assist for evaluating and reducing time intensive and expensive field tests (Whisler et al., 1986). Model results with regard to crop performance, management, and yield estimates will help decision makers to decide which management system is suited best for a particular field, by estimating the yield and crop water productivity optimum (Pawar et al., 2017). Some of the frequently applied crop models are: CropWat, CropSyst, AquaCrop, CERES, EPIC and DSSAT (Hunink and Droogers, 2011; Droogers and Hunink, 2012), APSIM and SPAC (Zhang et al., 2013). CropWat, AquaCrop and are specifically strong on the relationship between water availability, crop growth and climate change. In addition, these two models are in the public domain, have been applied worldwide frequently, and have a user-friendly interface (Hunink and Droogers, 2011). In contrast, the other models are complicated, require a large number of parameters and also require advanced skills from end-users for model calibration and operation (Heng et al., 2009). These disadvantages partly inhibit their developments and extensive applications for those models (Zhang et al., 2013).

Some specific features that distinguishes AquaCrop from other crop models as pointed out in available literature are: i) its focus on water; ii) use of canopy cover instead of leaf area index; iii) use of water productivity (WP) values normalised for atmospheric evaporative demand and $\mathrm{CO}_{2}$ concentration (Figures 1 and 2) that confer the model an extended extrapolation capacity to diverse locations, seasons, and climate, including future climate scenarios; iv) require relatively low number of parameters; v) input data which requires only explicit and mostly intuitive parameters and variables; vi) a well-developed user interface; vii) its considerable balance between accuracy, simplicity, and robustness; viii) its applicability to be used in diverse agricultural systems that exists worldwide.

In spite of the fact that, the model is relatively simple, it emphasises the fundamental processes involved in crop productivity and in the responses to water deficits, both from a physiological and an agronomic perspective.

\section{Operation and calculations}

Figure 3 depicts the model calculation scheme in a daily time step of simulations, and the model simulates sequentially the following parameters.

\section{Soil water balance}

The water stored in the root zone is simulated according for incoming and outgoing water fluxes at its boundaries. While, the depletion of root zone determines the magnitude of a set of water stress coefficients (Ks), which are affecting: i) green canopy (CC) expansion; ii) stomatal conductance and hence transpiration ( $\mathrm{Tr}$ ) per unit $\mathrm{CC}$; iii) canopy senescence and decline; vi) the harvest index (HI); and v) the root system deepening rate.

\section{Crop development}

AquaCrop uses canopy cover to describe crop development instead of leaf area index. The model is generally separated canopy expansion from the expansion of the root zone during simulation of crop development; therefore, the interdependence between shoot and root is indirect via water stress. CC is a crucial feature of AquaCrop through its expansion, ageing, conductance and senescence, it determines the amount of water transpired (Tr),

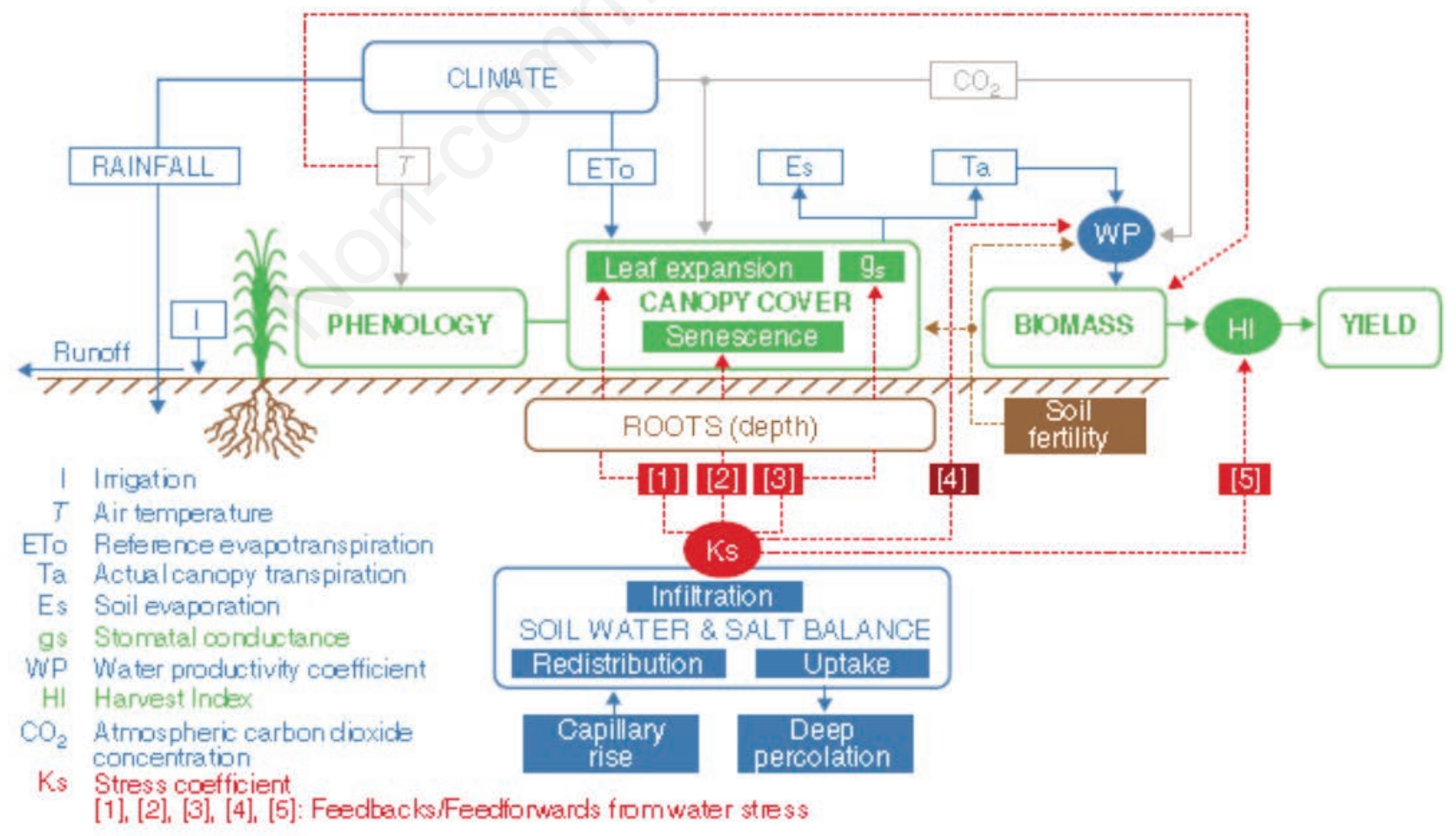

Figure 2. Flowchart of the AquaCrop model indicating the main components of the soil-plantatmospheric continuum (adapted from Abdul-Ganiyu et al., 2018 after a little modification from Raes et al., 2011). 
which in turns determines the amount of biomass produced (B) and the final yield $(\mathrm{Y})$. In circumstance of water stress, the simulated $\mathrm{CC}$ will be less than the potential canopy cover $\left(\mathrm{CC}_{\mathrm{pot}}\right)$ for the none stress conditions and the maximum rooting depth might not be reached (see the dark shaded areas in Figure 3) (Raes et al., 2011).

\section{Crop transpiration}

Crop transpiration is calculated by multiplying the evaporating power of the atmosphere $\left(\mathrm{ET}_{\mathrm{o}}\right)$ with a crop coefficient. The crop coefficient $\left(\mathrm{K}_{\mathrm{cb}}\right)$ is proportional to $\mathrm{CC}$ and hence continuously could be adjusted. The evaporating power is expressed by the reference grass evapotranspiration $\left(\mathrm{ET}_{\mathrm{o}}\right)$ as determined by the FAO Penman-Monteith equation (Allen et al., 1998). If water stress induces stomatal closure, the water stress coefficient for stomatal conductance $(\mathrm{Ks})$ reduces transpiration accordingly.

\section{Above ground biomass}

The cumulative amount of $\operatorname{Tr}$ translates into a proportional amount of biomass (B) produced through the biomass WP as in Eq. 1 (Steduto et al., 2007):

$\mathrm{B}=W P \cdot \sum T_{r}$

In AquaCrop the water productivity normalised for atmospheric demand and air $\mathrm{CO}_{2}$ concentrations (WP*) is used. It expresses the strong relationship between photosynthetic $\mathrm{CO}_{2}$ assimilation or biomass production and transpiration independently of the climatic conditions. Further away than the partitioning of biomass into yield described in the next paragraph, there is no partitioning of aboveground biomass among various organs.

\section{Partitioning of biomass into yield}

Crop yield is obtained with assistance of $\mathrm{HI}$ in case of simulated above ground B is available (Raes et al., 2011) as in Eq. 2:

$Y=H I . B$

Conditionally, the $\mathrm{HI}$ is continuously adjusted during yield formation in circumstance of crop yield response to water and/or temperature stresses.

\section{AquaCrop contribution on crop production and water use under different irrigation managements}

Recently, many studies have used the AquaCrop model to simulate various crops growth and production response to irrigation water and environments for different crops and regions maize

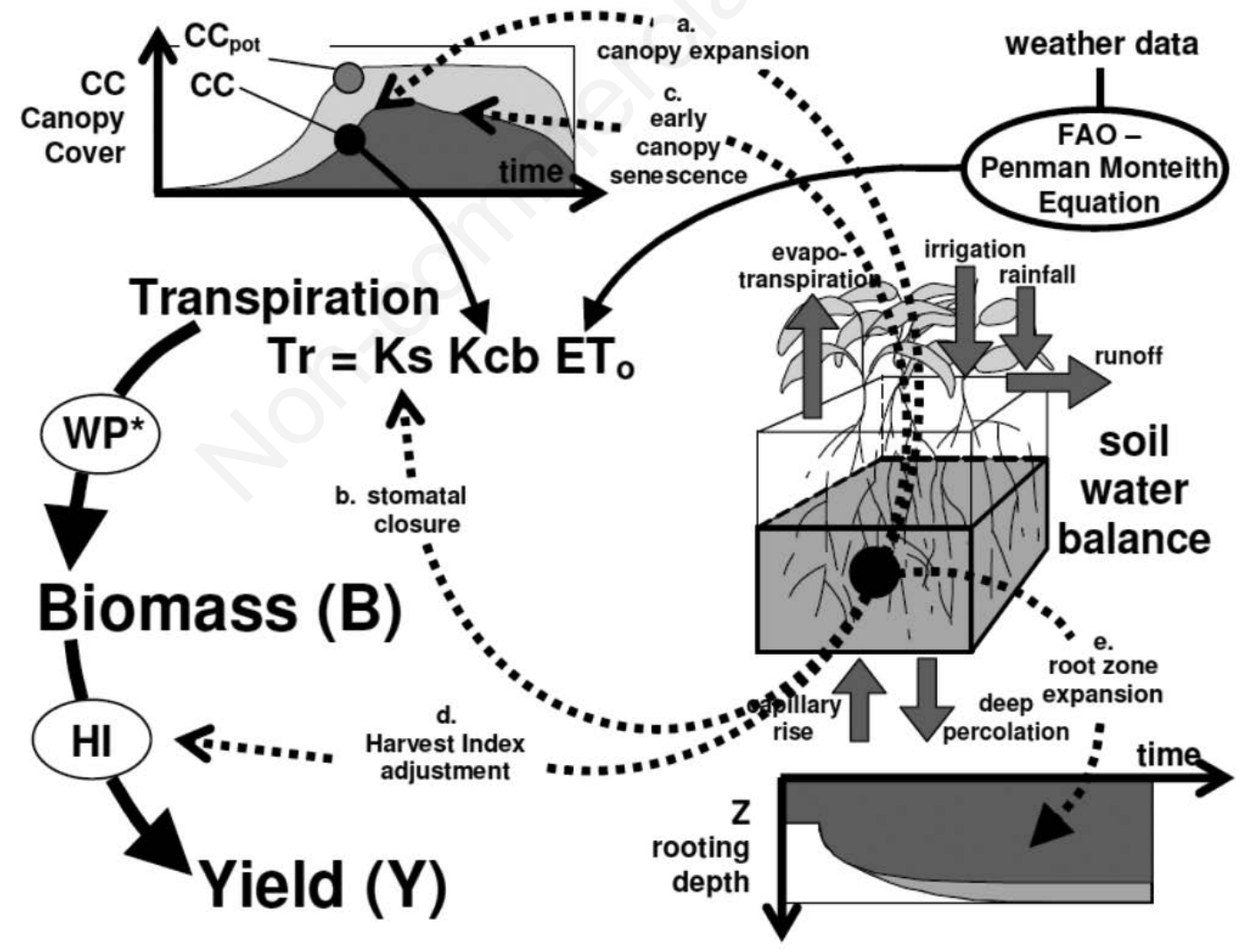

Figure 3. Calculation scheme of AquaCrop with indication (dotted arrows) of the processes (a to e) affected by water stress. [Source: Reference Manual, Chapter 1 - AquaCrop, Version 3.1plus January 2011, page 1-5 (adapted from Raes et al., 2011)]. CC, canopy cover; $\mathrm{CC}_{\mathrm{pot}}$, potential canopy cover; $K_{s}$, water stress coefficient; $K_{\mathrm{cb}}$, crop coefficient; $\mathbf{E T}_{\mathrm{o}}$, reference evapotranspiration; WP*, normalised crop water productivity; $\mathrm{HI}$, harvest index. 
(Heng et al., 2009; Hsiao et al., 2009; Salemi et al., 2011; FloresGallardo et al., 2013; Mhizha et al., 2014; Ahmadi et al., 2015; Greaves and Wang, 2016), cotton (Farahani et al., 2009; GarciaVila et al., 2009), sunflower (Stricevic et al., 2011), potato (Domínguez et al., 2011), cabbage (Wellens et al., 2013; Pawar et al., 2017), tef (Tsegay et al., 2012), wheat (Jamieson et al., 1991; Xiangxiang et al., 2013; Iqbal et al., 2014; Kumar et al., 2014), tomato (Rinaldi et al., 2011; Katerji et al., 2013; Linker et al., 2016), bambara groundnut (Karunaratne et al., 2011), quinoa (Geerts et al., 2009), barley (Araya et al., 2010; Abrha et al., 2012), canola (Zeleke et al., 2011), soybean (Khoshravesh et al., 2012), sugar beet (Stricevic et al., 2011) and rice (Lin et al., 2012; Shrestha et al., 2013b; Amiri et al., 2014).

Several tests have been done with AquaCrop in the term of deficit irrigation simulation and crop yield response to different water stress applications across wide regions in the world. Araya $e t$ al. (2010) tested AquaCrop for improving crop water use in East Africa (Ahmadi et al., 2015) simulated crop growth and soil water content under full and deficit irrigation managements in South of Iran (Greaves and Wang, 2016) evaluated irrigation management strategies for improving agricultural water use in Southern Taiwan. Pawar et al. (2017) used AquaCrop to improve water productivity of different irrigation strategies in India.

Many studies suggested more tests for calibration's key parameters in diverse climates, soils, crops, irrigation and field managements (Heng et al., 2009; Hsiao et al., 2009; Stricevic et al., 2011; Katerji et al., 2013; Zhang et al., 2013; Linker et al., 2016).

\section{Optimising water use in irrigation}

In several publication findings, authors stated some problems of relevance to irrigation practices and managements, such as: i) in many world areas irrigation delivery at the farm outlet is less or more than what is exactly required (Fereres and Soriano, 2006); ii) the high costs of irrigation and networks limit its benefits to reach the highest possible number of farmers; iii) inadequate estimation of the crop water requirements in large projects is another problem (English et al., 2002). On other hand, irrigated agriculture is still practiced in many areas in the world with complete disregard to basic principles of resource conservation and its sustainability. Therefore, irrigation water use in an era of water scarcity will have to be carried out more efficiently, aiming at saving water and at maximising its productivity (Fereres and Soriano, 2006) in order to optimise water use in irrigation (as explained later in Section Deficit irrigation and crop water response models).

In fact, optimisation of irrigation water use cannot be achieved without great effort due to the fact that some of the water losses are unavoidable. For example, water is needed to maintain the salt balance because irrigation waters contain salts and, as water evaporates, salts concentrate in the soil profile and must be displaced below the root zone before they reach a concentration that limits crop production. Salt leaching is achieved by the movement of water applied in excess of ET (Fereres and Soriano, 2006). Actually, for optimising water use must be controlled or minimised the two main losses components: one due to evaporation losses from the soil, and the other that includes all the losses resulting from the distribution of water to the land. As well as, reducing ET without a penalty in crop production is much more difficult, however, because evaporation from crop canopies is tightly coupled with the assimilation of carbon (Tanner and Sinclair, 1983; Monteith, 1990; Steduto et al., 2007). Furthermore, in any attempt to optimise water use for irrigation, there is significant uncertainty in the anticipated results and, often, the alternatives that anticipate higher net returns also have higher risks (English et al., 2002). To reduce uncertainty and risk, computer models that simulate irrigation performance (Lorite et al., 2005) e.g. AquaCrop model, together with social research, can aid in assisting water managers to optimise a limited supply of irrigation water (Fereres and Soriano, 2006). Finally, many investigations have been conducted to gain experiences in irrigation of crops to maximise performance, efficiency and profitability (Shankar et al., 2013). Some authors announced that, the amount of irrigation optimisation that can be achieved is crop-dependent and generally governed by amount of water extracted by plant roots (Ahmadi et al., 2011). So, investigations into water saving irrigation practices are still needed (Sleper et al., 2007).

\section{Deficit irrigation managements}

\section{The concept}

The conventional concept of DI is to provide irrigation water below the $\mathrm{ET}_{\mathrm{c}}$ requirements of the crops throughout the growing season. Nowadays the irrigation understanding replaced from maximise yield per planted area to yield per amount of water used. Therefore, the recent concept of DI is an optimisation strategy in which irrigation is applied during drought-sensitive growth stages of a crop (English, 1990; Geerts and Raes, 2009). Outside these periods, irrigation is limited or even unnecessary if rainfall provides a minimum supply of water. Water restriction is limited to drought tolerant stages, often the vegetative stages and the late ripening period (English, 1990). Indeed, while DI maximises irrigation water productivity, it also occurs inevitably results in plant stress and consequently in production loss due to unequal proportional quota of irrigation requirements throughout the crop cycle.

\section{Features of deficit irrigation}

Most irrigation systems are eligible to provide only between 30 to $50 \%$ of water that can be taken up by the plant (Sadras et al., 2007), while the DI is capable to increase this ratio to more than $90 \%$ in case of well-designed and management for the system (English, 1990; Sadras et al., 2007). DI is not only of high relevance in water-scarce areas or in dry seasonal periods; it also has the potential to optimise and reduce water use in irrigated systems for the humid and arid zones (Sadras et al., 2007). Deficit irrigation plays important role in drought periods, in regions with chronic water scarcity and the areas facing scarce resources like water. In mentioned situations, the water supply is restricted; therefore the farmers are often faced with having to use DI to achieve the highest possible returns or for trying to stabilise their productions. Even though the economics of DI are relatively straightforward (English, 1990), the reality is that, there are many engineering, social, institutional, and cultural issues that determine the distribution and the management of irrigation water (Fereres and Soriano, 2006). Finally, DI technique is maximising water productivity and enhanced harvest quality (Spreer et al., 2007). Additionally, since water use is reduced, the irrigated area can be increased and additional crops can be irrigated amplifying the diversity of the household production, which decreases the farmers' risks. The application of less water reduces the leaching effects of nutrients from the root-zone and agrochemicals, and the groundwater quality is preserved (Pandey et al., 2000). Furthermore, it reduces the risk of the 
development of certain diseases linked with high humidity that are common in other irrigation systems.

\section{Deficit irrigation and crop water response models}

The relationship between crop yield and water (Table 1) (Doorenbos and Kassam, 1979) used for AquaCrop model, is explained by a simple equation where relative yield reduction is related to the corresponding relative reduction in ET. This relationship in Eq. 3 is the following:

$$
\left(1-\frac{Y_{a}}{Y_{x}}\right)=K_{y} *\left(1-\frac{E T_{a}}{E T_{x}}\right)
$$

where $\mathrm{Y}_{\mathrm{a}}$ and $\mathrm{Y}_{\mathrm{x}}$ are actual and maximum yield (ton/ha), (1- $\left.\mathrm{Y}_{\mathrm{a}} / \mathrm{Y}_{\mathrm{x}}\right)$ is relative yield reduction, $\mathrm{ET}_{\mathrm{a}}$ and $\mathrm{ET}_{\mathrm{x}}$ are actual and maximum evapotranspiration $(\mathrm{mm}),\left(1-\mathrm{ET}_{\mathrm{a}} / \mathrm{ET}_{\mathrm{x}}\right)$ is relative water stress, and $\mathrm{K}_{\mathrm{y}}$ is yield response factor (proportionality factor between relative yield reduction and relative reduction in evapotranspiration. The yield response factor $\left(\mathrm{K}_{\mathrm{y}}\right)$ captures the essence of the complex linkages between production and water use by a crop, where many biological, physical and chemical processes are involved (Ismail et al., 2015).

\section{Crop water productivity}

In most of literature the crop water productivity defined as water use efficiency and calculated as the marketable crop yield over actual evapotranspiration (Zwart and Bastiaanssen, 2004), Eq. 4:

$$
C W P=\frac{Y_{\text {act }}}{E T_{\text {act }}}\left(\mathrm{kgm}^{-3}\right)
$$

where $\mathrm{Y}_{\text {act }}$ is the actual marketable crop yield $\left(\mathrm{kg} \mathrm{ha}^{-1}\right)$ and $\mathrm{ET}_{\text {act }}$ is the actual seasonal crop water consumption by evapotranspiration $\left(\mathrm{m}^{3} \mathrm{ha}^{-1}\right)$.

\section{Crop yield and irrigation water used of modelled crops}

Table 1 summarised researches data of recent publications related to full and deficit irrigation managements simulated with AquaCrop model. The study focused on modelled findings due to similarity of evaluated variables and methodologies used (testing/calibration, validation, evaluation and there is no possibility for unknown mistakes) where their results can help to figure out robust judgments for the model performance in related variables. Whereas the mentioned facts are not available for field observed results. The data describes various field crops (maize, wheat, soybean, sorghum, rice, cotton and quinoa) and vegetables/spices (Tomato, onion, potato, taro, cabbage, hot pepper and saffron) in different regions. Group 1, is usually used as edible, eaten by human and animals, its grains are highly nutritious. While, group 2 , is normally used by human, eaten as fresh vegetables or spice and flavoured sources (Table 1). The reduction in yields in Table 1, calculated as variation in percentage of less yield obtained in that study and its yield in full $\mathrm{ET}_{\mathrm{c}}$ (Eq. 5). Similarly, the water saved obtained as percentages of variation in maximum deficit water and full $\mathrm{ET}_{\mathrm{c}}$ used (Eq. 6). The two methods of calculations were found in previous publications (Rinaldi et al., 2011; Katerji et al., 2013; Linker et al., 2016; Pawar et al., 2017) as following:
Yield reduction $(\%)=\left(1-\frac{\text { Simulated Dl yield }(t / h a)}{\text { Simulated yield of full irrigation }(t / h a)}\right) * 100$

$W S P(\%)=\left(1-\frac{\text { DI water applied }(\mathrm{mm})}{\text { Full irrigation water used }(\mathrm{mm})}\right) * 100$

The yield in full irrigation management varied from 13.2 to 3.3 and 14.44 to $0.012 \mathrm{t} /$ ha for groups 1 and 2, respectively. In same line for deficit irrigation were ranged between 10.3 to $<0.1$ and 10.72 to $0.004 \mathrm{t} /$ ha (Table 1). While, the water applied as full $\mathrm{ET}_{\mathrm{c}}$ and maximum deficit in both groups 1 and 2 increased from 76843 and 95-1288 mm (min-max full $\mathrm{ET}_{\mathrm{c}}$ ) and 55(25\%)-596 (70\%), $17(17 \%)-800(30 \%) \mathrm{mm}$ (min-max deficit $\mathrm{ET}_{\mathrm{c}}$ ) for groups 1 and 2 , respectively. The big differences in crop yields and irrigation water applied refer to diverse climates and non-conservative crop parameters.

\section{Water saving potential}

For all studied publications the deficit irrigation managements varied between $80-17 \%$ water levels for hot pepper and potato crops respectively. Specifically, the variation of deficit percentages was $75-20 \%$ and $80-17 \%$ for crop groups 1 and 2, sequentially (Table 1). The diagrams in Figure 4 show the polynomial functions of simulated water saving and yield reduction for the previous publications. The highest correlation was 0.372 in group 1 followed by 0.117 in crop group 2, the relations are not strong but statistically reasonable in case of different type of evaluated crops and regions. Therefore, we recommend similar further studies for each crop as individual in the future. Regarding group 1, with accepting reduction in crop yield $2.66 \%$ can lead to save irrigation water equal to $23.68 \%$, while, when increasing the ratio to $29.03 \%$ help to gain $80 \%$ of water saving, this high percentage value refers to different climate for studied crops. In respecting group 2, 41.79\% of crop
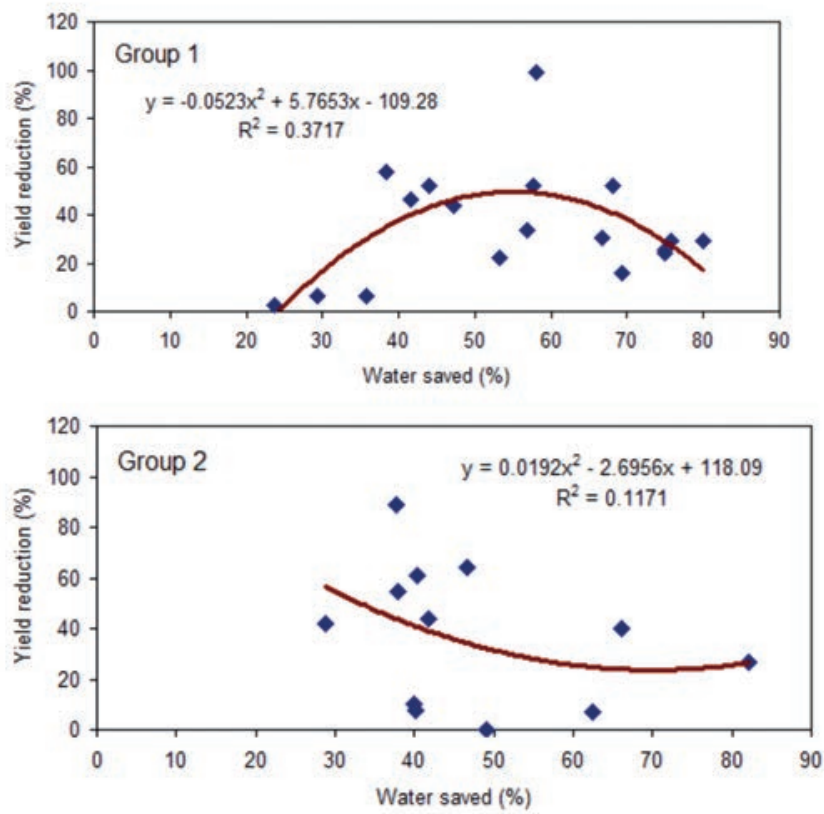

Figure 4. Relationship between irrigation water saving and yield reductions for crop group 1 and 2 . 
yield reduction saved $28.87 \%$ of water used and acceptance of $26.86 \%$ in yield reduction increased the water saving potential (WSP) equal to $82.1 \%$. The reason of obtained high WSP in less yield reduction in group 2, refer to the differences in full irrigation water requirements for various studied crop type. Therefore, when deciding to use the findings of this study, we strongly recommended for considering the diverse of local climates and differences in non-conservative crop parameters when simulate the deficit irrigation with AquaCrop model. The WSP obtained in this study higher than 20 to $50 \%$ that was reported by Shrestha et al. (2013a) for different deficit irrigation managements.

\section{Some findings, recommendations and proposed gaps}

Table 2, concludes brief of some published results and recommendations related to full and deficit irrigation managements in wide ranges of regions (humid, sub-humid and dry) around the world. For judging of overall performance of simulation model in full and deficit irrigation conditions, straightforward evaluation was made for the publication results in (Table 2). The authors used root mean square error, normalised root mean square error, coefficient of determination $\left(\mathrm{R}^{2}\right)$, model efficiency and index of agreement (D-index) in their evaluations (Loague and Green 1991; Jamieson et al., 1991; Bouman and Van Laar, 2006; Shabani et al., 2014; Stricevic et al., 2017). The overall performance varied between (acceptable and satisfactory) in full $\mathrm{ET}_{\mathrm{c}}$ and includes (less satisfactory, acceptable and satisfactory) for deficit $\mathrm{ET}_{\mathrm{c}}$.

Finally, the study suggests some points related to full and deficit irrigation management with AquaCrop model may need further studies as follows; A review investigation for each crop as individual either in Group 1 or Group 2 of this study and evaluate the big differences in crop yields and irrigation water applied simulated with AquaCrop under full and deficit irrigation management

Table 1. Effect of full and deficit irrigation on crop yield and water saving potential of different modelled crops.

\begin{tabular}{|c|c|c|c|c|c|c|c|c|}
\hline Crops & Exp. year & $\begin{array}{l}\text { Full } \mathrm{ET}_{\mathrm{c}} \\
(\mathrm{mm})\end{array}$ & $\begin{array}{l}\text { Max. defic. } \\
\text { (mm) }\end{array}$ & $\begin{array}{l}\text { Y. at full } \mathrm{ET}_{\mathrm{c}} \\
\text { (t/ha) }\end{array}$ & $\begin{array}{l}\text { Y. at max. } \\
\text { defic. (t/ha) }\end{array}$ & $\begin{array}{l}\text { Reduc. in yield } \\
(\%)\end{array}$ & $\begin{array}{c}\text { Water } \\
\text { saved (\%) }\end{array}$ & References \\
\hline Maize & $\begin{array}{l}1995 \\
2010-2011 \\
2014-2016 \\
1996-1997 \\
2009-2010\end{array}$ & $\begin{array}{c}568 \\
310(\mathrm{Sl}) \\
360(\mathrm{L \& cl}) \\
555 \text { (Exp.1) } \\
300 \text { (Exp.2) } \\
509 \\
498 \\
481.4 \\
\text { (Vali. N.L.F.L.) }\end{array}$ & $\begin{array}{c}174(33 \%)^{*} \\
75.0(25 \%) \\
90.0(25 \%) \\
235(33 \%) \\
140(33 \%) \\
372(\approx 50 \%) \\
338(\approx 50 \%) \\
447.4(50 \%)\end{array}$ & $\begin{array}{c}11.4 \\
\approx 3.4 \\
\approx 3.7 \\
11.0 \\
13.2 \\
10.4 \\
9.8 \\
5.85\end{array}$ & $\begin{array}{c}9.6 \\
\approx 2.4 \\
\approx 2.8 \\
5.3 \\
10.3 \\
\text { NA } \\
\text { NA } \\
5.89\end{array}$ & $\begin{array}{c}15.79 \\
29.4124 .32 \\
51.8221 .97 \\
\text { NA } \\
\text { NA } \\
-0.68\end{array}$ & $\begin{array}{c}69.37 \\
75.81 \\
75.00 \\
57.66 \\
53.33 \\
26.92 \\
32.13 \\
7.06\end{array}$ & $\begin{array}{l}\text { Heng et al. (2009) } \\
\text { Shrestha et al. } \\
\text { (2013a) } \\
\text { Greaves and Wang } \\
\text { (2016) } \\
\text { Katerii et al. } \\
\text { (2013) } \\
\text { Abedinpour et al. } \\
\text { (2012) }\end{array}$ \\
\hline Wheat & $\begin{array}{l}2010-2011 \\
2000-2005 \\
2008-2009 \text { (N.Y) } \\
2005-2006\end{array}$ & $\begin{array}{l}220 \\
300 \\
375 \\
534\end{array}$ & $\begin{array}{l}55(25 \%) \\
100(33 \%) \\
75(20 \%) \\
282(50 \%)\end{array}$ & $\begin{array}{c}\approx 4.3 \\
6.3 \\
8.68 \\
\mathrm{NA}\end{array}$ & $\begin{array}{l}\approx 3.2 \\
4.4 \\
6.16 \\
\text { NA }\end{array}$ & $\begin{array}{c}25.58 \\
30.16 \\
29.03 \\
44.1 \\
\end{array}$ & $\begin{array}{c}75.00 \\
66.67 \\
80 \\
47.19\end{array}$ & $\begin{array}{l}\text { Shrestha et al.(2013a) } \\
\text { Andarzian et al. (2011) } \\
\text { Xiangxiang et al. (2013) } \\
\text { Mohammadi et al. (2016) }\end{array}$ \\
\hline Soybean & 2011 & 393 & $138(52 \%)$ & NA & NA & NA & 64.89 & Khoshravesh et al. (2012) \\
\hline Sorghum & 2013-2014 & $\begin{array}{l}500 \text { (S.S) } \\
600 \text { (S.L) }\end{array}$ & $\begin{array}{l}210(58 \%) \\
370(38 \%)\end{array}$ & $\begin{array}{l}8.0 \\
8.4\end{array}$ & $\begin{array}{l}<0.1 \\
3.55\end{array}$ & $\begin{array}{l}98.75 \\
57.74\end{array}$ & $\begin{array}{c}58.0 \\
38.33\end{array}$ & Araya et al. (2016) \\
\hline Rice & 2008-2009 & 843 & $596(70 \%)$ & 6.06 & 5.67 & 6.44 & 29.30 & Maniruzzaman et al. (2015) \\
\hline Cotton & $\begin{array}{l}2005 \\
2008 \\
2008 \\
2009 \\
2010 \\
2011\end{array}$ & $\begin{array}{c}212 \\
329 \\
797 \\
758 \\
76 \\
635\end{array}$ & $\begin{array}{c}136(64 \%) \\
142(56 \%) \\
466(50 \%) \\
425(50 \%) \\
58(75 \%) \\
203(33 \%)\end{array}$ & $\begin{array}{c}5.11 \\
5.30 \\
5.4 \\
5.2 \\
3.38 \\
3.86 \\
\end{array}$ & $\begin{array}{c}4.78 \\
3.50 \\
2.9 \\
2.5 \\
3.29 \\
1.85\end{array}$ & $\begin{array}{c}6.46 \\
33.96 \\
46.30 \\
51.92 \\
2.66 \\
52.07 \\
\end{array}$ & $\begin{array}{l}35.85 \\
56.84 \\
41.53 \\
43.93 \\
23.68 \\
68.03 \\
\end{array}$ & $\begin{array}{l}\text { Linker et al. (2016) } \\
\text { Hussein et al.(2011) } \\
\text { Qiao (2012) }\end{array}$ \\
\hline Tomato & $\begin{array}{l}2007-2008 \\
2012\end{array}$ & $\begin{array}{l}485 \\
486 \\
259\end{array}$ & $\begin{array}{c}345(\approx 50 \%) \\
290(\approx 50 \%) \\
88(34 \%)\end{array}$ & $\begin{array}{c}6.7 \\
6.7 \\
7.26\end{array}$ & $\begin{array}{l}3.9 \\
2.6 \\
4.34\end{array}$ & $\begin{array}{l}41.79 \\
61.19 \\
40.22\end{array}$ & $\begin{array}{l}28.87 \\
40.33 \\
66.02\end{array}$ & $\begin{array}{l}\text { Katerji et al. (2013) } \\
\text { Linker et al. (2016) }\end{array}$ \\
\hline Onion & $\begin{array}{l}2008 \\
2009\end{array}$ & $\begin{array}{l}492 \\
474\end{array}$ & $\begin{array}{l}295(60 \%) \\
285(60 \%)\end{array}$ & $\begin{array}{l}3.05 \\
3.27\end{array}$ & $\begin{array}{l}2.81 \text { (B.D) } \\
2.94 \text { (B.D) }\end{array}$ & $\begin{array}{c}7.87 \\
10.09\end{array}$ & $\begin{array}{l}40.04 \\
39.87\end{array}$ & Nagaz et al. (2012) \\
\hline Potato & $\begin{array}{l}2012 \\
2013 \\
2011-2012\end{array}$ & $\begin{array}{l}216.6 \text { (Exp.1) } \\
220 \text { (Exp.2) } \\
95 \\
791.1\end{array}$ & $\begin{array}{c}110.2(49 \%) \\
82.5(62.5 \%) \\
17(17 \%) \\
550.7(60 \%)\end{array}$ & $\begin{array}{c}9.58 \\
11.52 \\
11.84 \\
14.44\end{array}$ & $\begin{array}{c}9.55 \\
10.72 \\
8.66 \\
10.06\end{array}$ & $\begin{array}{c}0.31 \\
6.95 \\
26.86 \\
30.33\end{array}$ & $\begin{array}{c}49.12 \\
62.5 \\
82.10 \\
30.39\end{array}$ & $\begin{array}{l}\text { Gebremedhin et al. (2015) } \\
\text { Linker et al. (2016) } \\
\text { Montoya et al. (2016) }\end{array}$ \\
\hline Taro & 2010-2011 & 1288 & $800(30 \%)$ & 1.14 & 0.52 & 54.39 & 37.89 & $\begin{array}{l}\text { Mabhaudhi et al.(2014a); } \\
\text { Mabhaudhi et al. (2013b) }\end{array}$ \\
\hline Hot pepper & 2010- 2011 & 452 & $282.0(80 \%)$ & 1.94 & 0.21 & 89.17 & 37.61 & Sam-Amoah et al. (2013) \\
\hline Saffron & 2004- 2005 & $\approx 300$ & $\approx 160(50 \%)$ & 0.012 & 0.0043 & 64.17 & 46.67 & Mirsafi et al. (2016) \\
\hline Quinoa & 2005-2006 & 137 & $80(\approx 60 \%)$ & NA & NA & NA & 41.61 & Geerts et al. (2009) \\
\hline Cabbage & $2013-2014$ & 247 & $144(60 \%)$ & 1.43 & 0.80 & 44.10 & 41.70 & Pawar et al. (2017) \\
\hline
\end{tabular}

*Values in parentheses are percentages of maximum deficient from full evapotranspiration (ETc); Reduc., Reduction; Max. defic., maximum deficient; adequ, adequate; Experimental year(s); NA, not available; Sl. sandy loam; L\&cl., loam and clay loam; Exp.1, Experiment (1); Vali. N.L.F.L., validation for non-limiting fertilised level; N.Y, normal year; S.S and S.L, Sandy Soil and Silt loam; B.D, bulbs dry yield. 
Table 2. Summary of overall performances and findings for AquaCrop model used in different locations.

\begin{tabular}{|c|c|c|c|c|}
\hline References & Location & $\begin{array}{l}\text { Overall model perfor. } \\
\text { in full ETc }\end{array}$ & $\begin{array}{l}\text { Overall model perfor. } \\
\text { in deficient conditions }\end{array}$ & Findings and Recommendations \\
\hline $\begin{array}{l}\text { Paredes et al. (2014); } \\
\text { Alves et al. (1991) }\end{array}$ & Portugal & A good performance & Adequacy performance & $\begin{array}{l}\text { The default parameters show less good performance } \\
\text { with acceptable errors which can be use when field } \\
\text { data are absence }\end{array}$ \\
\hline Araya et al. (2010) & Ethiopia & Adequate performance & Low performance & $\begin{array}{l}\text { The model can be used in the evaluation of irrigation } \\
\text { strategies and optimal planting time. The possibility } \\
\text { of obtaining more grain yield under deficit irrigation }\end{array}$ \\
\hline Mebane et al. (2013) & USA & NA & NA & $\begin{array}{l}\text { Model was accurately simulated the progression of } \\
\text { cumulative grain yield with time and reasonably well } \\
\text { in simulating the SWC at the six studied depths from } \\
(0.18-1.70 \mathrm{~m})\end{array}$ \\
\hline Ahmadi et al. (2015) & Iran & Satisfactorily & Insufficient accuracy & $\begin{array}{l}\text { Considered the model as a useful decision-making } \\
\text { tool for investigating deficit irrigations and suggested } \\
\text { the model should be included some calibrating } \\
\text { parameters about the root distribution pattern in the } \\
\text { soil for more benefit }\end{array}$ \\
\hline $\begin{array}{l}\text { Mkhabela and Bullock } \\
\text { (2012) }\end{array}$ & Canada & NA & NA & $\begin{array}{l}\text { Recommended to evaluate, validate and } \\
\text { fine-tuned the performance of the model under the } \\
\text { wider range of conditions and crops }\end{array}$ \\
\hline Farahani et al. (2009) & Syria & Accurate & Accurate & $\begin{array}{l}\text { Study provides first estimate values of cotton } \\
\text { parameters, it is useful for future model testing } \\
\text { and use. The key calibrated parameters are } \\
\text { site-specific, which they must to be tested under } \\
\text { different climate, soil, variety, irrigation methods, } \\
\text { and field management }\end{array}$ \\
\hline Trombetta et al. (2016) & Italy & NA & $\mathrm{NA}$ & $\begin{array}{l}\text { The model shows good estimations of the CC } \\
\text { development of winter wheat when used MODIS LAI } \\
\text { images as a measure of the vegetation cover } \\
\text { retrieved by remote sensing. Using remote sensing } \\
\text { with AquaCrop may lead to important improvements } \\
\text { in the evaluation of wheat yield at the regional scale } \\
\text { and to obtain acceptable estimates of each } \\
\text { hydrologic balance component, such as a space } \\
\text { and temporal variability of soil moisture }\end{array}$ \\
\hline $\begin{array}{l}\text { Mabhaudhi et al. } \\
\text { (2013a, 2014b) }\end{array}$ & $\begin{array}{l}\text { South } \\
\text { African }\end{array}$ & Well & Reasonable & $\begin{array}{l}\text { The minimal data requirements of model make it } \\
\text { particularly beneficial within the greater and } \\
\text { broader context of encouraging adoption of models, } \\
\text { as decision-making support tools in places were } \\
\text { access to extensive data sets might be limited. The } \\
\text { model should be used for modeling other neglected } \\
\text { and underutilised crops }\end{array}$ \\
\hline Karunaratne et al. (2011) & UK & Satisfactory & Satisfactory & $\begin{array}{l}\text { The validation results underestimated Y and other } \\
\text { crop parameters in variable climates. variation in the } \\
\text { quality and quantity of solar radiation have indirect } \\
\text { effects on simulations through ET0 calculations }\end{array}$ \\
\hline Geerts et al. $(2009,2010)$ & Bolivia & Satisfactory & Satisfactory & $\begin{array}{l}\text { Study derived DI schedules for quinoa in Bolivia. } \\
\text { Recommended a methodology to avoid drought } \\
\text { stress during the sensitive growth stages and to } \\
\text { guarantee maximum water productivity. } \\
\text { This methodology can be an illustrative decision } \\
\text { support tool for sustainable agriculture based on DI } \\
\text { in case it needs to applied on other crops and } \\
\text { regions. Finally, further improvements of the model } \\
\text { for soil nutrient depletion, pests, diseases, } \\
\text { and frost are also possible }\end{array}$ \\
\hline
\end{tabular}

Continued on next page. 
Table 2. Continued from previous page.

\begin{tabular}{|c|c|c|c|c|}
\hline References & Location & $\begin{array}{l}\text { Overall model perfor. } \\
\text { in full ETc }\end{array}$ & $\begin{array}{l}\text { Overall model perfor. } \\
\text { in deficient conditions }\end{array}$ & Findings and Recommendations \\
\hline Tavakoli et al. (2015) & Iran & Acceptable & Acceptable & $\begin{array}{l}\text { This model is able to optimise planting date under } \\
\text { water constraint environment for barley. } \\
\text { Also, can be used in the evaluation of crop irrigation } \\
\text { strategies }\end{array}$ \\
\hline Toumi et al. (2016) & Morocco & Acceptable & Acceptable & $\begin{array}{l}\text { The results proved that, early sowing is more ad } \\
\text { quate than late sowing in saving water and obtaining } \\
\text { adequate grain yield. value } 0.6 \text { of Dr, threshold is an } \\
\text { appropriate threshold of water depletion to improve } \\
\text { the wheat irrigation management. The model can be } \\
\text { useful tool for planning irrigation schedules in arid } \\
\text { and semi-arid regions after validation under real } \\
\text { conditions. For appropriate decisions, other studies } \\
\text { relative to economic and environmental analysis } \\
\text { should be performed in future }\end{array}$ \\
\hline $\begin{array}{l}\text { García-Vila } \\
\text { and Fereres (2012) }\end{array}$ & Spain & Satisfactory & Satisfactory & $\begin{array}{l}\text { The findings can support the suitability of the crop } \\
\text { parameters recommended by FAO (2010), } \\
\text { and illustrate the robustness and the general } \\
\text { applicability of AquaCrop. That beside the model } \\
\text { predicted a strong negative impact on farm income } \\
\text { of delaying a decision on the level of seasonal water } \\
\text { allocation by the water authority, reaching up to } \\
300 € \text { ha }^{-1} \text { in the case of the study area }\end{array}$ \\
\hline Adeboye et al. (2017) & Nigeria & Accurate & Accurate & $\begin{array}{l}\text { Good ability to optimise water productivity } \\
\text { of soybeans at farm level and basin scale in dry and } \\
\text { sub humid regions }\end{array}$ \\
\hline $\begin{array}{l}\text { Gebreselassie } \\
\text { et al. (2015) }\end{array}$ & Ethiopia & Adequate & Less satisfactory & $\begin{array}{l}\text { The model is less qualified for simulating treatments } \\
\text { with severe or prolonged water deficit below } 50 \% \text { of } \\
\text { ET. For improving crop yield in water deficit regions, } \\
\text { the model proved the possibility of obtained more } \\
\text { maize yield from less water used }\end{array}$ \\
\hline
\end{tabular}

ETc, evapotranspiration; NA, not available; CC, canopy cover; LAI, leaf area index; DI, deficit irrigation; FAO, Food and Agriculture Organisation.

as well as justification of high WSP corresponding less crop yield reduction. Application of the model with fruit trees in order to optimise its water use (Ismail et al., 2015). Testing the economic values and environmental analysis of the different irrigation schedules that were derived from the model simulation (Toumi et al., 2016). The effect of high temperature stress coefficient on HI to control overestimations of yield (Montoya et al., 2016). Further studies to define the terminology of severe water stress in deficit irrigation of major crops as numeric range, to avoid the mis-simulation of crop yield and water use.

\section{Conclusions}

Precise evaluations were made for data published from 1979 to 2018 related to full and deficit irrigation managements simulated with FAO-AquaCrop model. The objective was to evaluate the application of full and deficit irrigation $v s$ crop yield and water use for different crops (group 1 and 2) and regions around the world. In order to find the significance variations in modelled crop yield, irrigation water use and yield reductions corresponding to water saving potential. As well as, reporting brief summarise of findings, recommendations linked to model simulation and proposed some gaps for further investigations. The analysis showed that, there are significant differences in yield reductions corresponding to water saving. The polynomial correlation of $\mathrm{R}^{2}$ was 0.372 in group 1 and 0.117 in crop group 2, were not strong relation but acceptable due to the different type of studied crops and the big variation in their water needs. Model performance varied between (acceptable and satisfactory) in full $\mathrm{ET}_{\mathrm{c}}$ and (less satisfactory, acceptable and satisfactory) for deficit $\mathrm{ET}_{\mathrm{c}}$ managements. Simulated yield varied between 13.2 to 3.3 and 14.44 to $0.012 \mathrm{t} / \mathrm{ha}$ in full $\mathrm{ET}_{\mathrm{c}}$, and between 10.3 to $<0.1$ and 10.72 to $0.004 \mathrm{t} / \mathrm{ha}$ in deficit $\mathrm{ET}_{\mathrm{c}}$ for groups 1 and 2, respectively. In the term of WSP, accepting reduction in crop yield equivalent 2.66 and $29.03 \%$ save irrigation water equal to 23.68 and $80 \%$ in groups 1 , while the reduction of 41.79 and $26.86 \%$ of yield in crop groups 2 saved 28.87 and $82.1 \%$ of water used. The two maximum of water saving values are higher than water saved value that was reported for deficit irrigation in previous publications. The study also suggested some significant points related to full and deficit irrigation management with AquaCrop model need further studies e.g. evaluating the big differences in crop yields and irrigation water applied as well as justification of high WSP corresponding less crop yield reduction, testing the economic values and environmental analysis of the different irrigation schedules that were derived from the model simulation and defining the terminology of severe water stress in deficit irrigation of major crops as numeric range, to avoid the mis-simulation of crop yield and water use. 


\section{References}

Abdul-Ganiyu S, Kyei-Baffour N, Agyare WA, Dogbe W, 2018. Evaluating the Effect of Irrigation on Paddy Rice Yield by Applying the AquaCrop Model in Northern Ghana. In Strategies for Building Resilience against Climate and Ecosystem Changes in Sub-Saharan Africa. Springer, Singapore, pp. 93-116.

Abedinpour M, Sarangi A, Rajput T, Singh M, Pathak H, Ahmad T, 2012. Performance evaluation of AquaCrop model for maize crop in a semi-arid environment. Agric. Water Manage. 110:55-66.

Abrha B, Delbecque N, Raes D, Tsegay A, Todorovic M, Heng LEE, Vanutrecht E, Geerts SAM, Garcia-Vila M, Deckers S, 2012. Sowing strategies for barley (Hordeum vulgare L.) based on modelled yield response to water with AquaCrop. Exp. Agric. 48:252-71.

Adeboye OB, Schultz B, Adekalu KO, Prasad K, 2017. Modelling of response of the growth and yield of soybean to full and deficit irrigation by using Aquacrop. Irrig. Drain. 66:192-205.

Ahmadi SH, Mosallaeepour E, Kamgar-Haghighi AA, Sepaskhah AR, 2015. Modeling maize yield and soil water content with AquaCrop under full and deficit irrigation managements. Water Resour. Manage. 29:2837-53.

Ahmadi SH, Plauborg F, Andersen MN, Sepaskhah AR, Jensen CR, Hansen S, 2011. Effects of irrigation strategies and soils on field grown potatoes: Root distribution. Agric. Water Manage. 98:1280-90.

Alexandratos N, Bruinsma J, 2012. World agriculture towards 2030/2050: the 2012 revision. ESA Working paper No. 12-03. Rome, FAO. Available from: http://www.fao.org/fileadmin/ templates/esa/Global persepctives/world ag 2030 502012 rev.pdf

Allen RG, Pereira LS, Raes D, Smith M, 1998. Crop evapotranspiration: Guidelines for Computing Crop Water Requirements. FAO Irrigation and Drainage Paper No. 56, Rome, p. 1-333.

Alves IL, Fontes JC, Pereira LS, 1991. Water-yield relations for corn. In: Planning, Operation, and Management of Irrigation Systems for Water and Energy Conservation (Proc. Special Tech. Session). Chinese National Committee. ICID, Beijing, pp 154-161.

Amiri E, Rezaei M, Rezaei EE, Bannayan M, 2014. Evaluation of Ceres-Rice, Aquacrop and Oryza 2000 models in simulation of rice yield response to different irrigation and nitrogen management strategies. J. Plant Nutr. 37:1749-69.

Andarzian B, Bannayan M, Steduto P, Mazraeh H, Barati ME, Barati MA, Rahnama, A, 2011. Validation and testing of the AquaCrop model under full and deficit irrigated wheat production in Iran. Agric. Water Manage. 100:1-8.

Araya A, Habtu S, Hadgu KM, Kebede A, Dejene T, 2010. Test of AquaCrop model in simulating biomass and yield of water deficient and irrigated barley (Hordeum vulgare). Agric. Water Manage. 97:1838-46.

Araya A, Kisekka I, Holman J, 2016. Evaluating deficit irrigation management strategies for grain sorghum using AquaCrop. Irrig. Sci. 34:465-81.

Bouman B, Van Laar H, 2006. Description and evaluation of the rice growth model ORYZA2000 under nitrogen-limited conditions. AGR SYST. 87:249-73.

Domínguez A, Tarjuelo JM, De Juan JA, López-Mata E, Breidy J, Karam F, 2011. Deficit irrigation under water stress and salinity conditions: The MOPECO-Salt Model. Agric. Water
Manage. 98:1451-61

Doorenbos J, Kassam, AH, 1979. Yield Response to Water. FAO Irrigation and Drainage Paper No. 33. FAO, Rome, Italy, pp 193.

Droogers P, Hunink J, 2012. Assessment of impact of climate change on wheat in Armenia, Azerbaijan and Georgia. Regional analytical and advisory activities program on developing adaptation and mitigation strategies in the agricultural sector for Armenia, Azerbaijan and Georgia. Future Water 1:1-42.

English MJ, Solomon KH, Hoffman GJ, 2002. A paradigm shift in irrigation management. J. Irrig. Drain. Eng. 128:267-77.

FAO (Food and Agriculture Organisation of the United Nations), 2011. The State of the World's Land and Water Resources: Managing Systems at Risk. London, Earthscan. Available from: http://www.fao.org/docrep/017/i1688e/i1688e.pdf

Farahani HJ, Izzi G, Oweis TY, 2009. Parameterization and evaluation of the AquaCrop model for full and deficit irrigated cotton. Agron. J. 101:469-476.

Fereres E, Soriano MA, 2006. Deficit irrigation for reducing agricultural water use. J. Exp. Bot. 58:147-59.

Flores-Gallardo H, Ojeda-Bustamante W, Flores-Magdaleno H, Sifuentes-Ibarra E, Mejia-Saenz E, 2013. Simulation of corn (Zea mays 1.) yield in Northern Sinaloa using the AquaCrop model. Agroc.-Mex. 47:347-59.

Frenken K, Gillet V, 2012. Irrigation water requirement and water withdrawal by country. FAO, Rome, Italy.

García-Vila M, Fereres E, 2012. Combining the simulation crop model AquaCrop with an economic model for the optimization of irrigation management at farm level. Eur. J. Agron. 36:21-31.

Gebremedhin Y, Berhe A, Nebiyu A, 2015. Performance of AquaCrop model in simulating tuber yield of Potato (Solanum tuberosum L.) under various water availability conditions in Mekelle area, northern Ethiopia. JNSR. 5:123-30.

Gebreselassie Y, Ayana M, Tadele K, 2015. Field experimentation based simulation of yield response of maize crop to deficit irrigation using AquaCrop model, Arba Minch, Ethiopia. Afr. J. Agric. Res. 10:269-80.

Geerts S, Raes D, 2009. Deficit irrigation as an on-farm strategy to maximize crop water productivity in dry areas. Agric. Water Manage. 9:1275-84.

Geerts S, Raes D, Garcia M, 2010. Using AquaCrop to derive deficit irrigation schedules. Agric. Water Manage. 98:213-6.

Geerts S, Raes D, Garcia M, Miranda R, Cusicanqui JA, Taboada C, Mendoza J, Huanca R, Mamani A, Condori O, Mamani J, 2009. Simulating yield response of quinoa to water availability with AquaCrop. Agron. J. 101:499-508.

Greaves GE, Wang Y-M, 2016. Assessment of FAO AquaCrop Model for Simulating Maize Growth and Productivity under Deficit Irrigation in a Tropical Environment. Water-SUI. 8:557.

Heng LK, Evett SR, Howell TA, Hsiao TC, 2009. Calibration and testing of FAO aquacrop model for rainfed and irrigated maize. Agron. J. 101:488-98.

Hsiao TC, Heng L, Steduto P, Rojas-Lara B, Raes D, Fereres E, 2009. AquaCrop - the FAO crop model to simulate yield response to water: III. Parameterization and testing for maize. Agron. J. 101:448-59.

Hunink J.E, Droogers P, 2011. Climate change impact assessment on crop production in Uzbekistan. World Bank Study on Reducing Vulnerability to Climate Change in Europe and Central Asia (ECA) Agricultural Systems. Report Future Water 106.

Hussein F, Janat M, Yakoub A, 2011. Simulating cotton yield response to deficit irrigation with the FAO AquaCrop model. 
Span J Agric Res. 9:1319-30.

Iqbal MA, Shen Y, Stricevic R, Pei H, Sun H, Amiri E, Penas A, del Rio S, 2014. Evaluation of the FAO AquaCrop model for winter wheat on the North China Plain under deficit irrigation from field experiment to regional yield simulation. Agric. Water Manage. 135:61-72.

Ismail SM, El-Abedin TZ, El-Ansary D, Abdel-Al A, 2015. Modification of FAO Crop Model to Simulate Yield Response to Water for Peach Trees. Misr J. Ag. Eng. 32:145-72.

Jamieson PD, Porter JR, Wilson DR, 1991. A test of the computer simulation model ARCWHEAT1 on wheat crops grown in New Zealand. Field Crops Res. 27:337-50.

Joel S, Broner I, Wasksom RM, Rachel B, 2007. Colorado high plains irrigation practices guide: water saving options for irrigators in eastern Colorado. Special report (Colorado Water Resources Research Institute); no. 14. Available from: https://dspace.library.colostate.edu/bitstream/handle/10217/64 7/CWRRICHP100001.pdf? sequence=1\&isAllowed =y

Karunaratne AS, Azam-Ali SN, Izzi G, Steduto P, 2011. Calibration and validation of FAO-AquaCrop model for irrigated and water deficient bambara groundnut. Exp. Agric. 47:509-27.

Katerji N, Campi P, Mastrorilli M, 2013. Productivity, evapotranspiration, and water use efficiency of corn and tomato crops simulated by AquaCrop under contrasting water stress conditions in the Mediterranean region. Agric. Water Manage. 130:14-26.

Khoshravesh M, Mostafazadeh-Fard B, Heidarpour M, Kiani AR, 2012. AquaCrop model simulation under different irrigation water and nitrogen strategies. Water Sci. Technol. 67:232-8.

Kumar P, Sarangi A, Singh DK, Parihar SS, 2014. Evaluation of AquaCrop model in predicting wheat yield and water productivity under irrigated saline regimes. Irrig. Drain. 63:474-87.

Lin L, Zhang B, Xiong L, 2012. Evaluating yield response of paddy rice to irrigation and soil management with application of the AquaCrop model. Trans. ASABE. 55:839-48.

Linker R, Ioslovich I, Sylaios G, Plauborg F, Battilani A, 2016. Optimal model-based deficit irrigation scheduling using AquaCrop: A simulation study with cotton, potato and tomato. Agric. Water Manage. 163:236-43.

Loague KM, Green RE, 1991. Statistical and graphical methods for evaluating solute transport models: overview and application. J. Contam. Hydrol. 7:51-73.

Lorite IJ, Mateos L, Fereres E, 2005. Impact of spatial and temporal aggregation of input parameters on the simulation of performance of an irrigation scheme. J. Hydrol. 300:286-99.

Mabhaudhi T, Modi AT, Beletse YG, 2013a. Growth, phenological and yield responses of a bambara groundnut (Vigna subterranea L. Verdc) landrace to imposed water stress: II. Rain shelter conditions. Water SA. 39:191-8.

Mabhaudhi T, Modi AT, Beletse YG, 2013b. Response of taro (Colocasia esculenta L. Schott) landraces to varying water regimes under a rainshelter. Agric. Water Manage. 121:102-12.

Mabhaudhi T, Modi AT, Beletse YG, 2014a. Parameterisation and evaluation of the FAO-AquaCrop model for a South African taro (Colocasia esculenta L. Schott) landrace. Agric. For. Meteorol. 192:132-9.

Mabhaudhi T, Modi AT, Beletse YG, 2014b. Parameterization and testing of AquaCrop for a South African bambara groundnut landrace. Agron. J. 106:243-51.

Maniruzzaman M, Talukder MSU, Khan MH, Biswas JC, Nemes A, 2015. Validation of the AquaCrop model for irrigated rice production under varied water regimes in Bangladesh. Agric.
Water Manage. 159:331-40.

Mebane VJ, Day RL, Hamlett JM, Watson JE, Roth GW, 2013. Validating the FAO AquaCrop model for rainfed Maize in Pennsylvania. Agron. J. 105:419-27.

Mhizha T, Geerts S, Vanuytrecht E, Makarau A, Raes D, 2014. Use of the FAO AquaCrop model in developing sowing guidelines for rainfed maize in Zimbabwe. Water SA. 40:233-44.

Mirsafi ZS, Sepaskhah AR, Ahmadi SH, Kamgar-Haghighi AA, 2016. Assessment of AquaCrop model for simulating growth and yield of saffron (Crocus sativus L.). Sci. Hortic.Amsterdam. 211:343-51.

Mkhabela MS, Bullock PR, 2012. Performance of the FAO AquaCrop model for wheat grain yield and soil moisture simulation in Western Canada. Agric. Water Manage. 110:16-24.

Mohammadi M, Ghahraman B, Davary K, Ansari H, Shahidi A, Bannayan M, 2016. Nested validation of AquaCrop model for simulation of winter wheat grain yield, soil moisture and salinity profiles under simultaneous salinity and water stress. Irrig. Drain. 65:112-28.

Montoya F, Camargo D, Ortega JF, Córcoles JI, Domínguez A, 2016. Evaluation of Aquacrop model for a potato crop under different irrigation conditions. Agric. Water Manage. 164:267-80.

Nagaz K, Masmoudi MM, Ben Mechlia N, 2012. Yield response of drip irrigated onion under full and deficit irrigation with saline water in arid regions of Tunisia. ISRN Agronomy 212:562315.

Pandey RK, Maranville JW, Chetima MM, 2000. Deficit irrigation and nitrogen effects on maize in a Sahelian environment: II. Shoot growth, nitrogen uptake and water extraction. Agric. Water Manage. 46:15-27.

Paredes P, de Melo-Abreu JP, Alves I, Pereira LS, 2014. Assessing the performance of the FAO AquaCrop model to estimate maize yields and water use under full and deficit irrigation with focus on model parameterization. Agric. Water Manage. 144:81-97.

Pawar GS, Kale MU, Lokhande JN, 2017. Response of AquaCrop Model to Different Irrigation Schedules for Irrigated Cabbage. Agric. Res. 6:73-81.

Qiao X, 2012. Parameterization of FAO AquaCrop model for irrigated cotton in the humid southeast - US MS thesis. Clemson University, Department of Biosystems Engineering, Clemson, $\mathrm{SC}$, USA.

Raes D, Steduto P, Hsiao TC, Fereres E, 2009a. AquaCrop - the FAO crop model to simulate yield response to water: II. Main algorithms and software description. Agron. J. 101(3):438-447.

Raes D, Steduto P, Hsiao TC, Fereres E, 2009b. AquaCrop - The FAO crop model to simulate yield response to water: reference manual annexes. Available from: www.fao.org/nr/water/ aquacrop.html

Raes D, Steduto P, Hsiao TC, Fereres E, 2011. Chapter 1. FAO cropwater productivity model to simulate yield response to water AquaCrop. Reference Manual of AquaCrop, Version 3, pp.1-5.

Rinaldi M, Garofalo P, Rubino P, Steduto P, 2011. Processing tomatoes under different irrigation regimes in Southern Italy: agronomic and economic assessments in a simulation case study. J. Agrometeorol. 3:39-56.

Sadras VO, Grassini P, Steduto P, 2007. Status of water use efficiency of main crops SOLAW Background Thematic Report Status of Water Use Efficiency of major Crops FAO. Available from: http://www.fao.org/docrep/017/i1688e/i1688e.pdf

Salemi H, Soom MAM, Mousavi SF, Ganji A, Lee TS, Yusoff MK, Verdinejad VR, 2011. Irrigated silage maize yield and water productivity response to deficit irrigation in an arid region. Pol. 
J. Environ. Stud. 20:1295-303

Sam-Amoah LK, Darko RO, Owusu-Sekyere JD, 2013. Calibration and validation of AquaCrop for full and deficit irrigation of hot pepper. ARPN: JABS. 8:175-8.

Shabani A, Sepaskhah AR, Kamgar-Haghighi AA, 2014. Estimation of yield and dry matter of rapeseed using logistic model under water salinity and deficit irrigation. Arch. Agron. Soil Sci. 60:951-69.

Shankar V, Prasad KH, Ojha CSP, Govindaraju RS, 2013. Optimizing Water Use in Irrigation-A Review. J. Indian Inst. Sci. 93:209-26.

Shrestha N, Raes D, Sah SK, 2013a. Strategies to improve cereal production in the Terai region (Nepal) during dry season: simulations with Aquacrop. Procedia Environ. Sci. 19:767-75.

Shrestha N, Raes D, Vanuytrecht E, Sah SK, 2013b. Cereal yield stabilization in Terai (Nepal) by water and soil fertility management modeling. Agric. Water Manage. 122:53-62.

Sleper DA, Fales SL, Collins ME, 2007. Foreword. In: Irrigation of agricultural crops (R.J. Lascano and R.E. Sojka, eds.), 2nd edition, Agronomy Monograph no. 30. ASA-CSSA-SSSA publishing, pp 664.

Spreer W, Nagle M, Neidhart S, Carle R, Ongprasert S, Müller J, 2007. Effect of regulated deficit irrigation and partial rootzone drying on the quality of mango fruits (Mangifera indica L., cv. 'Chok Anan'). Agric. Water Manage. 88:173-80.

Steduto P, Hsiao TC, Fereres E, 2007. On the conservative behavior of biomass water productivity. Irrig. Sci. 25:189-207.

Steduto P, Hsiao TC, Raes D, Fereres E, 2009. AquaCrop - the FAO crop model to simulate yield response to water: I. Concepts and underlying principles. Agron. J. 101:426-37.

Stricevic R, Cosic M, Djurovic N, Pejic B, Maksimovic L, 2011. Assessment of the FAO AquaCrop model in the simulation of rainfed and supplementally irrigated maize, sugar beet and sunflower. Agric. Water Manage. 98:1615-21.

Stricevic R, Simic A, Kusvuran A, Cosic M, 2017. Assessment of AquaCrop model in the simulation of seed yield and biomass of Italian ryegrass. Arch. Agron. Soil Sci. 63:1301-13.

Tanner CB, Sinclair TR, 1983. Efficient water use in crop production: research or re-search?. In: Taylor HM, Jordan WR, Sinclair TR, eds. Limitations to efficient water use in crop production. Madison, WI: ASA, CSSA, SSSA, pp 1-27.

Tavakoli AR, Moghadam MM, Sepaskhah AR, 2015. Evaluation of the AquaCrop model for barley production under deficit irrigation and rainfed condition in Iran. Agric. Water Manage. 161:136-46.

Toumi J, Er-Raki S, Ezzahar J, Khabba S, Jarlan L, Chehbouni A, 2016. Performance assessment of AquaCrop model for esti- mating evapotranspiration, soil water content and grain yield of winter wheat in Tensift Al Haouz (Morocco): Application to irrigation management. Agric. Water Manage. 163:219-35.

Trombetta A, Iacobellis V, Tarantino E, Gentile F, 2016. Calibration of the AquaCrop model for winter wheat using MODIS LAI images. Agric. Water Manage. 164:304-16.

Tsegay A, Raes D, Geerts S, Vanuytrecht E, Abraha B, Deckers J, Bauer H, Gebrehiwot K, 2012. Unravelling crop water productivity of tef (Eragrostis Tef (Zucc.) Trotter) through AquaCrop in northern Ethiopia. Exp. Agric. 48:222-37.

Vanuytrecht E, Raes D, Steduto P, Hsiao TC, Fereres E, Heng LK, Vila MG, Moreno, PM, 2014. AquaCrop: FAO's crop water productivity and yield response model. Environ Model Softw. 62:351-60

Wellens J, Raes D, Traore F, Denis A, Djaby B, Tychon B, 2013. Performance assessment of the FAO AquaCrop model for irrigated cabbage on farmer plots in a semi-arid environment. Agric. Water Manage. 127:40-7.

Whisler FD, Acock B, Baker DN, Fye RE, Hodges HF, Lambert JR, Lemmon HE, McKinion JM, Reddy VR, 1986. Crop simulation models in agronomic systems. Adv. Agron. 40:141-208.

WWAP (World Water Assessment Programme), 2012. The United Nations World Water Development Report 4: Managing Water under Uncertainty and Risk. Paris, France. UNESCO. Available from: https://www.zaragoza.es/contenidos/medio ambiente/onu//newsletter12/789-eng-sum-ed4.pdf

Xiangxiang W, Quanjiu W, Jun F, Qiuping F, 2013. Evaluation of the AquaCrop model for simulating the impact of water deficits and different irrigation regimes on the biomass and yield of winter wheat grown on China's Loess Plateau. Agric. Water Manage. 129:95-104.

Zeleke KT, Luckett D, Cowley R, 2011. Calibration and testing of the FAO AquaCrop model for canola. Agron. J. 103:1610-8.

Zhang W, Liu W, Xue Q, Chen J, Han X, 2013. Evaluation of the AquaCrop model for simulating yield response of winter wheat to water on the southern Loess Plateau of China. Water Sci. Technol. 68:821-8.

Zwart SJ, Bastiaanssen WG, 2004. Review of measured crop water productivity values for irrigated wheat, rice, cotton and maize. Agric. Water Manage. 69:115-33.

2030 WRG (2030 Water Resources Group), 2009. Charting Our Water Future. The Barilla Group, The Coca-Cola Company, The International Finance Corporation, McKinsey \& Company, Nestlé S.A. Available from: http://www.2030 wrg.org/wp-content/uploads/2014/07/Charting-Our-WaterFuture-Final.pdf 